\title{
Gambaran Pengetahuan dan Sikap Siswa terhadap Makanan Jajanan Sebelum dan Setelah Pemberian Edukasi Kartu Kwartet Pada Anak Usia Sekolah Dasar di Kota Makassar
}

\author{
Aminuddin Syam ${ }^{1 *}, \mathrm{R}$ Indriasari ${ }^{1}$, In $\mathrm{Ibnu}^{2}$ \\ Program Studi Ilmu Gizi, FKM Univ.Hasanuddin, Makassar ${ }^{1}$ \\ STIK Tamalatea Makassar, Makassar² \\ amin.gzuh@gmail.com ${ }^{1 *}$
}

\begin{abstract}
Abstrak
Angka kejadian penyakit dan keracunan akibat makanan jajanan yang terjadi di kalangan anak usia sekolah saat ini meningkat. Anak usia sekolah memiliki kebiasaan jajan yang sulit untuk dihilangkan, sedangkan makanan jajanan yang tidak memenuhi syarat kesehatan dan gizi akan mengancam kesehatan anak sehingga diperlukan kemampuan anak dalam pemilihan jajanan yang tepat. Pengabdian masyarakat ini didanai oleh hibah internal Univ.Hasanuddin melalui LP2M, bertujuan untuk mendapatkan gambaran tentang pengetahuan dan sikap jajan sebelum dan setelah pemberian edukasi kartu kwartet pada anak usia sekolah di SD Negeri Inpres 1 Tamalanrea. Data dikumpulkan dari 80 siswa menggunakan kuesioner dan selanjutnya dianalisis menggunakan analisis deskriptif. Hasil menunjukkan bahwa tingkat pengetahuan anak usia sekolah tentang jajanan sehat terjadi peningkatan sebelum (pengetahuan tinggi n: 3 orang, 3,8\%) dan setelah (Pengetahuan tinggi $\mathrm{n}: 16,20 \%$ ) pemberian edukasi, dengan rata-rata peningkatan score pengetahuan (Mean $\pm \mathrm{SD}: 0,375 \pm 0,704, p: 0,00$ ). Sikap siswa terhadap jajanan sehat juga mengalami peningkatan sebelum (sikap positif n: 15 orang, 18,8\%) dan setelah pemberian edukasi kartu kwartet (sikap positif n: 58 orang, 72,5\%), dengan rata-rata peningkatan score sikap terhadap jajanan sehat (Mean \pm SD 1,075 $\pm 1,347, p: 0,00)$. Adanya perubahan pengetahuan dan sikap siswa membukti bahwa edukasi kartu kwartet menarik dan pesan didalamnya mampu dipahami dengan segera oleh siswa. Direkomendasikan kepada guru, orang tua dan instansi kesehatan untuk menggunakan media/metode pendidikan gizi yang tepat untuk anak usia sekolah dasar.
\end{abstract}

Kata Kunci: Anak Usia Sekolah; Pengetahuan Jajan; Sikap Jajan; Jajanan Sehat.

\section{Pendahuluan}

Masalah kesehatan di usia dewasa sebagian berkaitan dengan perilaku kesehatan ataupun gaya hidup di usia muda termasuk di usia remaja dan anak-anak. Perilaku hidup sehat sejak usia dini merupakan salah satu upaya yang cukup penting dalam menciptakan sumber daya manusia yang produktif dan berkualitas di masa yang akan datang. Beberapa perilaku berisiko pada anak-anak diantaranya adalah kebiasaan merokok, gizi tidak seimbang, kurang aktifitas fisik, hygiene dan sanitasi individu, jajanan tidak sehat, kebiasaan sarapan yang kurang.

Kesehatan pada usia sekolah menjadi penting karena adanya keterkaitan antara kesehatan dan fungsi akademik karena periode ini merupakan periode belajar, pertumbuhan dan perkembangan. Anak usia sekolah adalah investasi bangsa, karena mereka adalah generasi penerus bangsa. Kualitas bangsa di masa depan ditentukan oleh kualitas anak-anak saat ini. Tumbuh berkembangnya anak usia sekolah yang optimal tergantung pemberian nutrisi dengan kualitas dan kuantitas yang baik.

Pada tahun 2011, South East Asian Nutrition Survey (SEANUTS) melaksanakan survei untuk mengetahui status gizi anak (usia 6 bulan - 12 tahun) di negara-negara Asia Tenggara termasuk Indonesia. Survei melibatkan lebih dari 7.200 anak di 48 kabupaten/kota di Indonesia. Dibandingkan dengan negara lain di Asia Tenggara, status gizi anak Indonesia masih relatif lebih rendah, dimana kasus stunting masih tinggi dengan prevelansi 25,2\% untuk perkotaan dan 39,2\% untuk pedesaan; berat dan tinggi badan secara rata-rata masih di 
bawah standar WHO; kekurangan Vitamin D dengan prevelansi $43 \%$ untuk perkotaan dan 44,2\% untuk pedesaan; dan $70 \%$ anak tidak sarapan.

Sedangkan prevalensi obesitas pada kelompok umur 6-14 tahun berdasarkan Riskesdas 2007 di Sul-Sel terdapat 7,4\% laki-laki dan 4,8\% perempuan. Hasil studi Survei Diet Total (2014) menyebutkan bahwa rata-rata tingkat asupan kalori anak-anak umur 5-12 tahun di perkotaan Sulawesi Selatan adalah $1.650 \mathrm{kkal}$ yang mana masih dibawah Angka Kecukupan Energi yaitu 1.911 kkal. Sedangkan rata-rata tingkat asupan kalori anak-anak umur 5-12 tahun di pedesaan Sulawesi Selatan adalah $1.578 \mathrm{kkal}$.

Pemberian nutrisi atau asupan makanan pada anak dalam masa tumbuh kembang tidak selalu dapat dilaksanakan dengan sempurna, karena sering timbul masalah seperti maraknya penggunaan zat-zat berbahaya dalam makanan, perilaku anak mengkonsumsi jajanan yang tidak aman dan kurangnya pengawasan orang tua terhadap perilaku jajan anak. Penggunaan zat berbahaya dalam makanan dan perilaku jajan tidak sehat ini dapat mengakibatkan gangguan pada organ-organ dan sistem tubuh anak. Perilaku jajanan tidak sehat biasanya minim dalam hal kandungan gizinya yang berguna untuk tubuh, jajanan yang tidak sehat biasanya terdiri dari kandungan gula atau pengganti gula yang tinggi (manis, penambahan perasa buah dsbnya), tinggi lemak (gurih, gorengan, berminyak), serta pewarna buatan yang beranekaragam.

WHO menjelaskan bahwa di antara sejumlah perilaku yang tidak sehat, pola makan merupakan salah satu faktor utama tingginya angka kematian yang diakibatkan oleh kanker dan jantung koroner (Wardle et al., 1997). Obesitas termasuk konsekuensi jangka pendek dari pola makan yang tidak sehat. Obesitas berpengaruh terhadap konsekuensi jangka panjang, seperti stroke, diabetes, jantung koroner, kanker, dan macam penyakit kronis lainnya.

Permasalahannya jumlah orang yang mengalami obesitas juga semakin bertambah. Data yang dikumpulkan WHO (Sharma, 2011) menunjukkan bahwa 10\% anak-anak di dunia mengalami obesitas dan pada umumnya obesitas menetap sampai usia dewasa. Menurut Data Riskesdas 2013, prevalensi obesitas pada anak-anak (6-14 tahun) adalah 9,5\% laki-laki dan 6,4\% perempuan. Angka obesitas pada anak-anak di Indonesia hampir sama dengan estimasi WHO sebesar 10\%. Semakin bertambahnya jumlah anak Indonesia yang mengalami obesitas disebabkan karena anak-anak juga suka makan di luar rumah, seperti rumah makan fastfood. Anak-anak di usia sekolah sudah mulai dapat memilih dan menentukan makanan yang disukai, serta suka sekali 'jajan'. Jajan yang dibeli adalah seperti es, gula-gula atau makanan lain yang tinggi kalori dan lemak, serta rendah serat (Wijayanti, 2007).

Hasil studi asupan karbohidrat hubungannya dengan kegemukan/obesitas pada anak sekolah dasar di SD Athirah menyebutkan bahwa Karbohidrat merupakan faktor risiko terjadinya obesitas pada anak SD Athirah. Nilai OR=3,14 berarti risiko obesitas 3,14 kali lebih tinggi pada anak yang mempunyai asupan karbohidrat risiko tinggi dibandingkan anak dengan asupan karbohidrat risiko rendah. Begitupun dengan asupan lemak tinggi, Nilai $\mathrm{OR}=4,50$ berarti risiko obesitas 4,5 kali lebih tinggi pada anak yang mempunyai asupan lemak risiko tinggi dibandingkan anak dengan asupan lemak risiko rendah. Sedangkan asupan protein merupakan faktor protektif terhadap obesitas.

Masalah lain yang dihadapi anak usia sekolah yaitu rendahnya tingkat keamanan pangan jajanan anak sekolah (PJAS) masih menjadi permasalahan penting. Data pengawasan PJAS yang dilakukan BPOM (Balai Besar Pengawasan Obat dan Makanan) RI cq Direktorat Inspeksi dan Sertifikasi Pangan bersama 26 Balai Besar/Balai POM di seluruh Indonesia pada tahun 2007 menunjukkan bahwa 45\% PJAS tidak memenuhi syarat karena mengandung 
bahan kimia berbahaya seperti formalin, boraks, rhodamin, mengandung bahan tambahan pangan (BTP), seperti siklamat dan benzoat melebihi batas aman serta mengandung bakteri S. aureus dan E. Coli melebihi batas (BPOM RI, 2009). Data KLB keracunan pangan Badan POM RI menunjukkan bahwa 19\% kejadian keracunan terjadi di lingkungan sekolah dan dari kejadian tersebut kelompok siswa sekolah dasar (SD) paling sering $(78,57 \%)$ mengalami keracunan PJAS (BPOM RI, 2009). Hasil penelitian (BPOM) dalam lima tahun terakhir (2006-2010) menunjukkan, sebanyak 40-44 \% jajanan anak di sekolah tidak memenuhi syarat keamanan pangan.

\section{Latar Belakang Teori}

Anak sekolah menurut definisi WHO (World Health Organization) yaitu golongan anak yang berusia antara 7-15 tahun, sedangkan di Indonesia lazimnya anak yang berusia 7-12 tahun. Menurut Gunarsa (2008), masa anak usia sekolah adalah masa tenang atau masa latent dimana apa yang telah terjadi dan dipupuk pada masa-masa sebelumnya akan berlangsung terus untuk masa-masa selanjutnya. Tahap usia ini disebut juga sebagai usia kelompok dimana anak mulai mengalihkan perhatian dan hubungan intim dalam keluarga kerjasama antar teman dan sikap-sikap terhadap kerja atau belajar.

Makanan jajanan menurut Food and agricultural organization (FAO) adalah makanan dan minuman yang dipersiapkan dan dijual oleh pedagang kaki lima di jalanan dan di tempattempat keramaian umum lain yang langsung dimakan atu dikonsumsi tanpa pengolahan atau persiapan lebih lanjut. Istilah makanan jajanan tidak jauh dari istilah junk food, fast food, dan street food karena istilah tersebut merupakan bagian dari istilah makanan jajanan (Aprillia, 2011). Makanan jajanan terdiri dari minuman, makanan kecil (kudapan), dan makanan lengkap, didefinisikan sebagai makanan yang siap untuk dimakan atau terlebih dahulu dimasak di tempat penjualan, dan di jual di pinggir jalan, atau tempat umum (Winarno, 1993).

Perilaku konsumen merupakan studi tentang cara individu, kelompok, dan organisasi menyeleksi, membeli, menggunakan, dan memposisikan barang, jasa, gagasan, atau pengalaman untuk memuaskan kebutuhan dan keinginan mereka (Kotler \& Keller, 2013). Moehji (1993, dalam Safriana 2012) mengemukakan anak-anak usia sekolah sudah cenderung dapat memilih makanan yang disukai dan mana yang tidak. Anak-anak mempunyai sifat yang berubah-ubah terhadap makanan. Seringkali anak memilih makanan yang salah terlebih lagi jika tidak dibimbing oleh orang tuanya. Selain itu anak lebih sering menghabiskan waktu diluar rumah sehingga anak lebh sering menemukan aneka jajanan baik yang dijual disekitar sekolah, lingkungan bermain ataupun pemberian teman. Anak usia sekolah dasar selalu ingin mencoba makanan yang baru dikenalnya. Dalam pemilihan jajanan juga terdapat beberapa cara untuk memilih jajanan yang sehat, diantaranya adalah 1) menghindari jajanan yang dijual di tempat terbuka, kotor dan tercemar, tanpa penutup dan tanpa kemasan, 2) memilih dan membeli hanya jajanan pangan yang dijual di tempat bersih dan terlindung dari matahari, debu, hujan, angin dan asap kendaraan bermotor, 3) memilih tempat yang bebas dari serangga dan sampah, 4) menghindari pangan yang dibungkus dengan kertas bekas atau koran, 5) membeli pangan yang dikemas dengan kertas, plastik atau kemasan lain yang bersih dan aman, 6) menghindari pangan yang mengandung bahan pangan sintetis berlebihan atau bahan tambahan pangan terlarang dan berbahaya (Zein, 2010).

Memilih adalah sebuah gambaran perilaku seseorang dalam mengambil keputusan (Aprillia, 2011). Perilaku adalah cara seseorang untuk bertindak atau berkelakuan yang sama dan harus di ikuti oleh semua anggota yang ada di lingkungannya. Sehingga perilaku merupakan hasil 
dari pengalaman dan proses interaksi dengan lingkungan yang terwujud dalam bentuk pengetahuan, sikap dan tindakan (Maulana, 2009).

Menurut (Shepherd, R \& Sparks, P, 1999) pemilihan jajanan merupakan hal yang kompleks karena dalam proses pembuatan keputusan, konsumen akan bergantung pada faktor yang mempengaruhi baik dalam proses pencarian informasi dan pengambilan keputusan. Faktor yang mempengaruhi pemilihan makanan dibagi menjadi tiga faktor yaitu faktor terkait makanan, faktor personal berkaitan dengan pengambilan keputusan pemilihan makanan, dan faktor sosial ekonomi. Anak telah memiliki urutan atribut produk yang penting dalam pembelian makanan. Atribut-atribut tersebut adalah rasa, harga, merek dan promosi (Triwijayati, Armanu \& Solimun, 2011).

\section{Metode}

Penelitian ini dilakukan di Sekolah Dasar Inpres 1 Tamalanrea. Rancangan penelitian adalah pre-post one group yaitu satu kelompok siswa kelas V diberikan permainan kartu kwartet tentang jajanan sehat selama 4 minggu, pre-test dilakukan 1 minggu sebelum intervensi dan post-test dilakukan 1 minggu setelah intervensi. Media edukasi berupa kartu kwartet disusun sendiri oleh tim peneliti, yang terdiri dari 12 sub tema pesan gizi dan jajanan sehat yaitu : 1 . Status Gizi Anak Sekolah, 2. Buah-Buahan yang mengandung vitamin C; 3. Buah-buahan sumber vitamin A; 4. Makanan sumber protein; 5. Makanan sumber karbohidrat; 6. Makanan sumber lemak; 7. Sayuran hijau sumber zat besi; 8. Perilaku Hidup Bersih di Sekolah; 9. Perilaku Jajan tidak sehat anak SD; 10. Pencemaran pada jajanan anak SD; 11. Dampak mengonsumsi jajanan tidak sehat; dan 12. Cara untuk menghindari mengonsumsi jajan yang tidak sehat. Pre-post test dinilai dengan menggunakan kuesioner. Kuesioner dibuat sendiri oleh peneliti dengan mengembangkan teori food choice dari Shepher \& Spark. Kuesioner langsung diisi oleh responden dengan adanya pendampingan dari peneliti saat proses pengisian kuesioner. Populasi dan sampel penelitian ini adalah seluruh siswa kelas V sebanyak 80 siswa. SD Inpress Tamalanrea 1 terpilih sebagai tempat pengabdian dikarenakan lokasinya strategis yaitu berada ditengah-tengah pusat kota, disekitarnya terdapat warungwarung kelontong dan pasar yang merupakan pusat jajanan anak sekolah.

\section{Hasil dan Diskusi}

Hasil penelitian tentang pemilihan makanan jajanan pada anak usia sekolah di SD inpres 1 Tamalanrea adalah sebagai berikut :

Tabel 1. Distribusi Karakteristik Anak Usia Sekolah SD Inpres 1 Tamalanrea $(n=80$ siswa)

\begin{tabular}{llll}
\hline No. & Karakteristik & n (orang) & \% \\
\hline 1. & Jenis Kelamin & & \\
& Laki-laki & 33 & $41,3 \%$ \\
& Perempuan & 47 & $58,8 \%$ \\
\hline & Jumlah & 80 & $100 \%$ \\
\hline
\end{tabular}

\begin{tabular}{llll}
\hline No. & Karakteristik & n (orang) & \% \\
\hline 2. & Umur siswa & & \\
& $<10$ tahun & 11 & $13,8 \%$ \\
& $\geq 10$ tahun & 69 & $86,3 \%$ \\
\hline & Jumlah & 80 & $100 \%$ \\
\hline 3. & Agama & & \\
\hline
\end{tabular}




\begin{tabular}{|c|c|c|c|}
\hline & Islam & 71 & $88,8 \%$ \\
\hline & Kristen & 5 & $6,2 \%$ \\
\hline & Hindu & 4 & $5,0 \%$ \\
\hline & Jumlah & 80 & $100 \%$ \\
\hline \multirow[t]{6}{*}{4.} & Pekerjaan Orang tua (Ayah) & & \\
\hline & PNS & 9 & $11,3 \%$ \\
\hline & Karyawan swasta & 31 & $38,8 \%$ \\
\hline & Wiraswasta & 22 & $27,5 \%$ \\
\hline & Lainnya & 18 & $22,4 \%$ \\
\hline & Jumlah & 80 & $100 \%$ \\
\hline \multirow[t]{7}{*}{5.} & $\begin{array}{l}\text { Pendidikan terakhir orang } \\
\text { (Ayah) }\end{array}$ & & \\
\hline & Tidak sekolah & 3 & $3,8 \%$ \\
\hline & $\mathrm{SD}$ & 0 & $0 \%$ \\
\hline & SMP & 6 & $7,5 \%$ \\
\hline & SMA & 47 & $58,8 \%$ \\
\hline & Diploma/Sarjana/Magister & 24 & $30 \%$ \\
\hline & Jumlah & 80 & $100 \%$ \\
\hline
\end{tabular}

Tabel 2.

Distribusi Gambaran Pola Konsumsi Jajanan Anak Usia Sekolah SD Inpres 1 Tamalanrea $(n=80$ siswa)

\begin{tabular}{|c|c|c|c|}
\hline No. & Pola Jajanan anak sekolah & n (orang) & $\%$ \\
\hline \multirow[t]{6}{*}{1.} & Frekuensi Jajan per Hari & & \\
\hline & Tidak pernah & 2 & $2,5 \%$ \\
\hline & $1-3$ kali & 13 & $16,3 \%$ \\
\hline & 3-5 kali & 49 & $61,3 \%$ \\
\hline & $>5$ kali & 16 & $20,0 \%$ \\
\hline & Jumlah & 80 & $100 \%$ \\
\hline \multirow[t]{5}{*}{2.} & Alasan Utama Jajan di sekolah* & & \\
\hline & Diberi uang saku & 12 & $15 \%$ \\
\hline & Tidak membawa bekal dari rumah & 37 & $46,3 \%$ \\
\hline & Tidak sempat sarapan & 42 & $52,5 \%$ \\
\hline & Banyak pedagang jajanan kecil disekitar sekolah & 40 & $50 \%$ \\
\hline \multirow[t]{5}{*}{3.} & Tempat Jajanan siswa di sekolah & & \\
\hline & Kantin dalam sekolah & 29 & $36,3 \%$ \\
\hline & Pedagang jajanan di pinggir jalan & 20 & $25 \%$ \\
\hline & Warung di luar sekolah & 31 & $38,7 \%$ \\
\hline & Jumlah & 80 & $100 \%$ \\
\hline \multirow[t]{7}{*}{4.} & Faktor Pemilihan Makanan jajanan* & & \\
\hline & Tektur, bentuk dan warna jajanan & 4 & $5 \%$ \\
\hline & Rasa jajanan manis dan bervariasi & 29 & $36,3 \%$ \\
\hline & Pengaruh teman sebaya & 6 & $7,5 \%$ \\
\hline & Cepat disajikan dan porsi banyak & 8 & $10 \%$ \\
\hline & Harga yang murah & 33 & $41,3 \%$ \\
\hline & Jumlah & 80 & $100 \%$ \\
\hline
\end{tabular}

*setiap siswa boleh memilih lebih dari satu pilihan 
Tabel 3.

Distribusi Tingkat Pengetahuan dan Sikap Siswa Terhadap Jajanan Sehat Anak Usia Sekolah Sebelum Intervensi (Pre-test) SD Inpres 1 Tamalanrea $(n=80$ siswa)

\begin{tabular}{llll}
\hline No. & Variabel & n (orang) & \% \\
\hline 1. & Pengetahuan tentang Jajanan Sehat: & & \\
& Rendah & 45 & $56,3 \%$ \\
& Sedang & 32 & $40 \%$ \\
& Tinggi & 3 & $3,8 \%$ \\
\hline & Jumlah & 80 & $100 \%$ \\
\hline 2. & Sikap terhadap Jajanan sehat : & & \\
& Negatif & 65 & $81,3 \%$ \\
& Positif & 15 & $18,8 \%$ \\
\hline & Jumlah & 80 & $100 \%$ \\
\hline
\end{tabular}

Sumber : Data Primer, 2018

Tabel 6.

Distribusi Tingkat Pengetahuan dan Sikap Siswa Terhadap Jajanan Sehat Anak Usia Sekolah Setelah Intervensi (Post-test) SD Inpres 1 Tamalanrea $(n=80$ siswa)

\begin{tabular}{llll}
\hline No. & Variabel & n (orang) & \% \\
\hline 1. & Pengetahuan tentang Jajanan Sehat: & & \\
& Rendah & 13 & $16,3 \%$ \\
& Sedang & 51 & $63,7 \%$ \\
& Tinggi & 16 & $20,0 \%$ \\
\hline & Jumlah & 80 & $100 \%$ \\
\hline 2. & Sikap terhadap Jajanan sehat : & & \\
& Negatif & 22 & $27,5 \%$ \\
& Positif & 58 & $72,5 \%$ \\
\hline & Jumlah & 80 & $100 \%$
\end{tabular}

Sumber : Data Primer, 2018

Tabel 8.

Analisis Perbandingan Mean Pengetahuan dan Sikap Terhadap Jajanan Sehat sebelum dan setelah intervensi (pre-post test) di SD Inpres 1 Tamalanrea

\begin{tabular}{lccll}
\hline Variabel & N & Mean & $\begin{array}{l}\text { Std. } \\
\text { Deviation }\end{array}$ & $\begin{array}{l}\text { Sig } \\
\text { tailed)* }\end{array}$ \\
\hline Pengetahuan Siswa & 80 & 0,375 & 0,704 & 0,00 \\
\hline Sikap Siswa & 80 & 1,075 & 1,347 & 0,00
\end{tabular}

*Uji paired t-test (Data Primer, 2018)

Berdasarkan hasil penelitian ini, karakteristik siswa usia sekolah dasar yaitu SD Inpres 1 Tamalanrea adalah berdasarkan jenis kelamin, perempuan sebanyak 58,8\%, laki-laki sebanyak 41,3\%. Umur siswa kelas V dominan berumur atau lebih dari 10 tahun (86,3\%), sebagian besar juga beragama islam $(88,8 \%)$. Pekerjaan orang tua sebagian besar PNS $(38,8 \%)$ dan Wiraswasta $(27,5 \%)$. Sementara pendidikan terakhir orang tua sebagian besar lulusan SMA $(58,8 \%)$ dan lulusan diploma/sarjana/magister sebanyak 30\%. Melihat karakteristik tersebut maka siswa di SD Inpres 1 Tamalanrea berada pada tingkatan keluarga 
menengah ke bawah. Karakteristik siswa tidak terlalu dominan sehingga tidak mempengaruhi pola jajanan siswa.

Pemilihan makanan jajanan pada anak usia sekolah di masa modern ini dalam keadaan yang tidak baik. Indikator yang termasuk kedalam pemilihan makanan jajanan yang tidak baik dalam penelitian ini diantaranya adalah pola jajanan, pemilihan jenis makanan jajanan, faktor pemilihanan makanan jajanan, tingkat pengetahuan siswa dan sikap siswa terhadap jajanan sehat. Dengan demikian maka anak harus merubah pola pemilihan yang tidak baik menjadi baik, sebagaimana menurut data BPOM tentang kejadian luar biasa keracunan pangan menunjukkan bahwa $19 \%$ kasus keracunan terjadi di sekolah dan sekitar 78,57\% menimpa anak sekolah dasar (BPOM, 2011).

Dalam penelitian ini, daftar jajanan yang tersedia di SDN Inpres 1 Tamalanrea diakui sekolah telah diawasi dengan baik dan sesuai dengan ketentuan, diantaranya kerupuk pabrikan, mie instan, nasi kuning, gorengan, aneka permen, aneka minuman pabrikan, bakso, siomai. Akan tetapi banyaknya warung kelontong dan pasar tradisional yang terletak di luar lingkungan sekolah dan kemudahan siswa keluar masuk membeli jajanan menyebabkan pengawasan harus tetap diperketat. Anak-anak mempunyai sifat yang berubah-ubah terhadap makanan (Safriana, 2012). Kebutuhan fisik dan psikis anak juga menjadi dasar quick evaluation atau evaluasi alternatif pilihan jajanan dan pengambilan keputusan pembelian makanan jajanan oleh konsumen anak yang tidak terencana. Jenis pengambilan keputusan (Impulsivity) yang mungkin terjadi pada anak secara signifikan berkontribusi memprediksi perilaku lebih dan di atas perilaku yang terencana (planned behavior). Anak dapat mengambil keputusan antara lain pada saat dan pada apa yang mereka inginkan untuk dimakan (Triwijayati, Armanu \& Solimun, 2011). Seringkali anak memilih makanan yang salah terlebih lagi jika tidak dibimbing oleh orang tuanya.

Hasil dari penelitian ini menyatakan bahwa pola jajan siswa SDN Inpres 1 Tamalanrea adalah frekuensi jajan perhari siswa cukup tinggi (siswa jajan 3-5 kali perhari $=61,3 \%$ ). Alasan utama siswa memilih jajan di sekolah adalah dikarenakan tidak sempat sarapan $(52,5 \%)$, dan banyaknya pedangan kecil di sekitar sekolah (50\%). Sarapan pagi pada umumnya menyumbang gizi sekitar 25\% dari angka kebutuhan gizi sehari. Anak yang tidak sarapan pagi cenderung mengonsumsi energi dan zat gizi lebih sedikit daripada anak yang sarapan pagi. Berdasarkan penelitian Apriani, 2011, di SDN Pekunden Semarang menunjukkan hasil uji hubungan antara frekuensi sarapan pagi dengan pemilihan makanan jajanan menunjukkan angka $p=0,730$ berarti bahwa tidak terdapat hubungan yang signifikan antara kedua variabel tersebut.

Pemilihan makanan jajanan terkait faktor makanan menyebutkan bahwa sebanyak 41,3\% dari responden memilih jajanan karena harganya murah. Sebanyak 36,3\% yang memilih jajanan karena faktor rasanya manis dan bervariasi. Sub indikator yang termasuk ke dalam faktor personal diantaranya yaitu pemilihan jajanan terkait rasa (flavor) dan aroma. Anak sekolah dasar menganggap rasa lebih penting daripada kandungan gizi dalam membeli jajanan. Penelitian yang dilakukan oleh Suci (2009) tentang pemilihan jajanan terkait rasa menyatakan bahwa $84 \%$ responden anak membeli jajanan karena enak rasanya. Hal ini perlu mendapat perhatian lebih lanjut karena rasa enak untuk anak sekolah dapat dijadikan alasan penjaja makanan untuk memberi bumbu penyedap makanan, meicin, dan lainnya, agar makanan yang dijajakan laku di pasar tanpa memperhatikan faktor kesehatan. Disamping itu makanan yang memiliki rasa manis terlalu berlebihan juga tidak baik karena penambahan pemanis buatan, kalori makanan manis yang cukup tinggi juga bisa menyebabkan obesitas pada masa anak-anak. 
Pengetahuan juga salah satu faktor yang mempengaruhi pemilihan makanan jajanan. Pengetahuan adalah hasil tahu, dan ini terjadi setelah orang melakukan penginderaan terhadap suatu objek tertentu. Penginderaan terjadi melalui pancaindera manusia. Sebagian besar pengetahuan manusia diperoleh melalui mata dan telinga. Pengetahuan atau kognitif merupakan domain yang sangat penting untuk terbentuknya tindakan seseorang (overt behaviour). Hal ini didasarkan pada pengalaman berbagai penelitian yang menyatakan bahwa perilaku yang didasari pengetahuan akan lebih tahan lama daripada perilaku yang tidak didasari oleh pengetahuan. Pengetahuan termasuk di dalamnya pengetahuan gizi, jajan, dan makanan jajanan dapat diperoleh melalui pendidikan formal maupun informal (Triwijayati, Armanu \& Solimun, 2011).

Berdasarkan hasil penelitian ini, tingkat pengetahuan siswa di SD Inpres 1 Tamalanrea tentang jajanan sehat sebelum pemberian edukasi berupa permainan kwartet masih sangat rendah, presentasi siswa dengan tingkat pengetahuan rendah yaitu 56,3\%, tingkat pengetahuan sedang sebanyak $40 \%$ dan tingkat pengetahuan tentang jajanan sehat yang tinggi hanya 3,8\% sedangkan setelah diberikan edukasi terdapat kenaikan tingkat pengetahuan jajanan sehat pada anak SD yaitu pengetahuan rendah menjadi $16,3 \%$, pengetahuan sedang meningkat menjadi $63,7 \%$ dan pengetahuan tinggi menjadi $20,0 \%$. Rata-rata score tingkat pengetahuan siswa sebelum dan setelah intervensi kartu kwartet meningkat sebanyak rata-rata (Mean \pm SD : 0,375 $\pm 0,704$ ), signifikan secara statistik $\mathrm{p}=0,000$.

Hasil penelitiani ini berbeda dengan dengan hasil penelitian Aini, tahun 2016 di SDN Klurak Candi Sidoarjo Kelas 5, yang memberikan intervensi berupa penyuluhan jajanan sehat berupa video. Peningkatan pengetahuan hanya terjadi pada pada kontrol, bukan pada kelompok intervensi, setelah diteliti ternyata mayoritas kelompok kontrol mendapat informasi sebelumnya dari guru kelas dan teman. Akan tetapi hasil peningkatan pengetahuannya tidak signifikan secara statistik. Sedangkan hasil penelitian dengan intervensi media ceramah dan komik menunjukkan hasil yang hampir serupa yaitu Pada kelompok ceramah menunjukkan bahwa terdapat perbedaan yang signifikan tentang pengetahuan pemilihan jajanan sehat sebelum dan sesudah diberi pendidikan gizi dengan metode ceramah. Akan tetapi hasil peningkatan pengetahuan kelompok yang diintervensi dengan media komik lebih tinggi (skor pengetahuan kelompok komik meningkat sebesar 3,72 poin). Pada anak kelas 5 yang dijadikan sebagai responden penelitian, cocok menggunakan metode komik dikarenakan anak-anak usia 10 - 12 tahun mulai menyukai cerita yang bersifat kritis dibandingkan dengan anak usia 6 - 8 tahun yang lebih tertarik untuk membaca dan mendengar dongeng fantasi (Hartono, dkk. 2015).

Selain itu, sikap siswa terhadap jajanan sehat juga meningkat ke arah sikap positif yaitu sebelum intervensi edukasi sikap siswa yang memilih jajanan kurang sehat yaitu sebanyak 81,3\% (sikap negatif), sedangkan siswa yang memiliki sikap memilih jajanan sehat hanya (sikap positif) $18,8 \%$. Persentasi sikap siswa setelah intervensi edukasi kartu kwartet menjadi sikap negatif menurun menjadi $27,5 \%$, dan yang memiliki sikap positif terhadap jajanan sehat menjadi $72,5 \%$. Peningkatan score sikap siswa rata-rata cukup tinggi yaitu Mean $\pm \mathrm{SD}=1,075$ $\pm 1,347, \mathrm{p}=0,000$.

Berdasarkan hasil penelitian Perdana, dkk, (2015) di SD Islam Hidayatullah Denpasar Selatan dengan memberikan intervensi peer-group-tutorial yaitu rata-rata tingkat sikap siswa tentang jajan sehat sebelum diberikan metode peer group tutorial adalah 67,8 yang termasuk dalam kategori baik. Sedangkan untuk nilai rata-rata tingkat sikap siswa tentang jajan sehat setelah diberikan metode peer group tutorial adalah 92,1 yang termasuk dalam kategori sangat baik. Tingginya peningkatan sikap siswa dibandingkan tingkat pengetahuan siswa dikarenakan Menurut Sunaryo (2004), sikap tidak dibawa sejak lahir tetapi dapat dipelajari dan dibentuk berdasarkan pengalaman individu sepanjang perkembangan selama hidupnya. 
Pembentukan sikap dipengaruhi oleh faktor eksternal (pengalaman, situasi, norma, hambatan dan pendorong) dan internal (fisiologis, pendidikan, psikologis dan motif). Oleh karena karena sikap seseorang tidaklah tetap, tapi bisa berubah-ubah.

Pengetahuan sebagian besar diperoleh melalui indera penglihatan (30\%) dan indera pendengaran (10\%). Permainan kartu kwartet jajanan sehat ini dapat meningkatkan perhatian, konsentrasi dan imajinasi anak kemudian anak tersebut diharapkan mulai belajar menerapkan hal yang dipelajari sehingga akhirnya dapat membentuk pengetahuan dan sikap yang baik akan tetapi masih dibilang baru dikalangan siswa-siswa SD yang terbiasa dengan permainan game online. Media gizi yang sangat sering digunakan dibeberapa penelitian adalah puzzle gizi, komik, video edukasi, ular tangga dan lain-lain, melihat pengaruh yang diberikan hampir sama maka kartu kwartet dapat menjadi alternatif permainan meningkatkan pengetahuan dan sikap jajan siswa SD (Hikmawati dkk 2016).

\section{Kesimpulan}

Simpulan dari penelitian ini adalah pengaruh permainan kartu kwartet pada siswa SD yaitu terdapat peningkatan presentasi dan skor pengetahuan jajanan sehat pada siswa SD sebelum dan setelah intervensi. Disamping itu, sikap siswa terhadap jajanan sehat juga mengalami perubahan signifikan dari negatif menjadi positif. Dengan demikian, kartu kwartet dapat menjadi alternatif media gizi yang menarik dan bermanfaat untuk siswa SD.

Didapatkan hasil bahwa gambaran pola konsumsi jajanan, pemilihan jajanan serta pengetahuan dan sikap siswa SDN Inpres 1 Tamalanrea sebagian besar berada pada pemilihan tidak baik. Hal ini berpengaruh terhadap kesehatan siswa khususnya beresiko terhadap kerusakan organ pencernaan. Untuk itu perlu adanya upaya guru, orang tua dan instansi kesehatan (puskesmas) untuk bekerja sama dalam mengatasi masalah ini melalui pendidikan, perhatian serta pengawasan pada anak. Pemilihan makanan jajanan pada anak perlu lebih diperhatikan untuk menghindari efek yang akan terjadi terhadap pertumbuhan dan perkembangan anak.

\section{Ucapan Terima Kasih}

Tim peneliti mengucapkan terima kasih kepada SD Inpres Tamalanrea 1 sebagai tempat kegiatan pengabdian masyarakat, serta kepada LP2M Unhas sebagai lembaga yang memfasilitasi pendanaan untuk kegiatan pengabdian masyarakat ini.

\section{Daftar Pustaka}

Agustiningsasi, dkk. (2017). Hubungan antara Paparan Iklan Makanan dan Minuman Ringan di Televisi dengan Perilaku Pemilihan Jajanan ajanan pada Anak (Studi Analitik pada Anak dengan Status dengan Status dengan Status Gizi Lebih Sekolah Dasar di Kab.Jember). e-Jurnal Pustaka Kesehatan, Vol. 5, No. 2.

Aini, N. (2016). Mengubah Perilaku Jajan Sembarangan Pada Siswa Sekolah Dasar Melalui

Penyuluhan Kesehatan. Journal Of Nursing Care \& Biomolecular, Vol. 1 No. 1.

Aisyiyah. (2015). Pola Asuh Dan Pengaruh Teman Sebaya Terhadap Pemilihan Jajan Anak Usia Sekolah Di Kelurahan Cirendeu Tangerang Selatan. Jurnal Care Vol. 3, No. 2.

Amir, M, dkk. (2012). Analisis Penerimaan Media Komunikas (Poster) Tentang Jajanan

Sehat di Kalangan Siswa Sekolah Dasar di Kota Samarinda. Jurnal Promosi Kesehatan NUSANTARA. No.10 Edisi 10. Juli Desember 2012.

Aprillia, B.A. (2011). Faktor yang Berhubungan dengan Pemilihan Makanan Jajanan pada Anak Sekolah Dasar. Program Studi Ilmu Gizi Fakultas Kedokteran .Universitas Diponegoro : Semarang. 
Hamida, K dan Zulaekah. (2012). Penyuluhan Gizi Dengan Media Komik Untuk Meningkatkan Pengetahuan Tentang Keamanan Makanan Jajanan. Jurnal KEMAS Vol.8 No.1. Tahun 2012. Hal. 67-73.

Hartono, N.P, dkk. (2015). Pendidikan Gizi tentang Pengetahuan Pemilihan Jajanan Sehat antara Metode Ceramah dan Metode Komik. Indonesian Journal of Human Nutrition, Desember 2015, Vol.2 No.2: $76-84$.

Hikmawati, dkk. (2016). Pengaruh Penyuluhan Dengan Media Promosi Puzzle Gizi Terhadap Perilaku Gizi Seimbang Pada Siswa Kelas V Di SD Negeri 06 Poasia Kota Kendari. Fakultas Kesehatan Masyarakat Universitas Halu Oleo.

Iklima, N. (2017). Gambaran Pemilihan Makanan Jajanan Pada Anak Usia Sekolah Dasar. Jurnal Keperawatan BSI, Vol.5 No.1.

Kristianto, dkk. (2013). Faktor Determinan Pemilihan Makanan Jajanan pada Siswa Sekolah Dasar. Kesmas, Jurnal Kesehatan Masyarakat Nasional Vol. 7, No. 11.

Maesarah. (2010). Faktor Risiko Kejadian Obesitas Pada Anak SS Islam Athira Kota Makassar. Universitas Islam Negeri : Makassar.

Noviani, K, dkk. (2016). Kebiasaan jajan dan pola makan serta hubungannya dengan status gizi anak usia sekolah di SD Sonosewu Bantul Yogyakarta. Jurnal Gizi dan Dietetik Indonesia, Vol.4 No.2., hal. 97-104.

Nuryadin. (2014). Perihal Jajanan Anak Sekolah Dalam Perspektif Perlindungan Konsumen. Fakultas Hukum Universitas Azzahra, Jakarta.

Pakhri, A, dkk. (2014). Pengetahuan Dan Kebiasaan Konsumsi Makanan Jajanan Pada Anak SDN Baddoka Makassar. Media Gizi Pangan, Vol. XVIII, Edisi 2.

Perdana, N.W.L, dkk. (2014). Pengaruh Peer Group Tutorial Terhadap Perilaku Jajan Sehat Siswa Kelas 3 Di SD Islam Hidayatullah Denpasar Selatan. Program Studi Ilmu Keperawatan Fakultas Kedokteran Universitas Udayana, Denpasar.

Putra, A.E dan Subagio, H.W. (2014). Gambaran Kebiasaan Jajan Siswa Di Sekolah. Program Studi Ilmu Gizi Fakultas Kedokteran. Universitas Diponegoro, Semarang.

Yustisa, P.F, dkk. (2014). Efektifitas Penggunaan Media Cetak dan Media Elektronik dalam Promosi Kesehatan Terhadap Peningkatan Pengetahuan dan Perubahan Sikap Siswa SD. Jurnal Kesehatan Lingkungan Vol.4 No.1, hal. 29-39. 